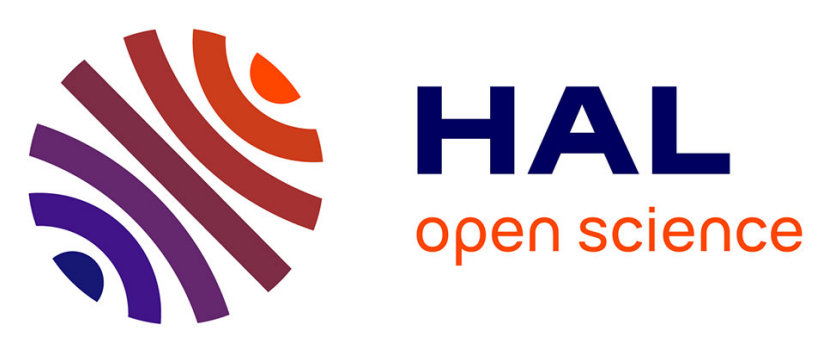

\title{
French residents are inadequately trained in the prevention of complications related to air travel
}

Diane Naouri, Frédéric Lapostolle, Claire Rondet, Olivier Ganansia, Dominique Pateron, Youri Yordanov

\section{- To cite this version:}

Diane Naouri, Frédéric Lapostolle, Claire Rondet, Olivier Ganansia, Dominique Pateron, et al.. French residents are inadequately trained in the prevention of complications related to air travel. Travel Medicine and Infectious Disease, 2018, 24 (July-August 2018), pp.10-11. 10.1016/j.tmaid.2018.06.003 . hal-02064235

\section{HAL Id: hal-02064235 \\ https://hal.sorbonne-universite.fr/hal-02064235}

Submitted on 11 Mar 2019

HAL is a multi-disciplinary open access archive for the deposit and dissemination of scientific research documents, whether they are published or not. The documents may come from teaching and research institutions in France or abroad, or from public or private research centers.
L'archive ouverte pluridisciplinaire HAL, est destinée au dépôt et à la diffusion de documents scientifiques de niveau recherche, publiés ou non, émanant des établissements d'enseignement et de recherche français ou étrangers, des laboratoires publics ou privés. 
French residents are inadequately trained in the prevention of complications related to air travel

\section{A R T I C L E I N F O}

Keywords:

Travel medicine

Medical education

Primary care

Dear Editor,

Medical issues related to air travel are estimated at about 350 annually, corresponding to $1 / 14,000-40,000$ passengers [1]. Specific conditions of air travel - biophysical in particular - are responsible for most of these medical issues [2,3]. In healthy subjects, the physiological impact of these situations is usually asymptomatic [1]. But air travel can put some patients (i.e. patients with underlying conditions and multimorbid patients) at risk of medical emergencies [2]. General practitioners (GPs) are usually the first physicians consulted before air travel $[4,5]$. We therefore seeked to evaluate general-practice residents' knowledge about air travel related diseases and to explore the factors associated with this knowledge.

In this letter we report the results of an anonymous survey of general-practice residents we ran in the greater Paris area in 2013. The questionnaire was divided into four principal sections with 10 questions in total: demographic characteristics, travel-medicine education, knowledge regarding diseases related to air travel, and prevention of these complications. Every resident was attributed a grade of knowledge ranging from 0 to 20 by summing 1 ) the number of correct answers regarding diseases related to air travel among the 17 proposed and 2) the number of correct responses concerning times to respect before three events and flight: a) myocardial infarction without complications; b) abdominal surgery and c) scuba diving. Internal consistency of the grading system was satisfactory (Cronbach alpha $=0.70$ ).

Among the 600 surveyed residents, 392 answered (response rate $65 \%$ ). The mean knowledge grade was $6.5 \pm 3.2$ (out of 20 ), with the highest grade 16. Having an experience of pre-travel consultation was the only factor associated with a grade above versus below the median $(p=0.01)$ (Table 1). There were no significant differences between the two groups regarding the other factors. About $2 \%(n=8 / 92)$ of residents reported having benefited from a specific training in pathologies related to air travel. On our sample of respondents, we found that re- sidents had poor knowledge of diseases related to air travel. Having the experience of pre-travel consultation was the only variable associated with residents' knowledge and our result underlined that medical education regarding this specific topic remains insufficient. Even though, much of pre-travel consultation is assured by GPs, lack of medical education regarding diseases related to air travel could negatively affect prevention in primary care. For example, several measures, such as pulse oximeter and the $50-\mathrm{m}$ walk test, are available in the primary care setting to assess patients need of supplemental inflight

Table 1

Characteristics of the study population.

\begin{tabular}{lllll}
\hline & TOTAL & GRADE $\leq 6$ & GRADE $>6$ & $\mathrm{p}$ \\
\hline $\mathbf{N}$ (\%) & 392 & $211(53.8)$ & $181(46.2)$ & \\
Age & & & & \\
$\quad<26$ years & $207(52.8)$ & $110(53.1)$ & $97(46.9)$ & 0.7731 \\
$\quad \geq 26$ years & $185(47.2)$ & $101(54.6)$ & $84(45.4)$ & \\
Gender & & & & \\
$\quad$ Male & $108(27.6)$ & $50(46.3)$ & $58(53.7)$ & 0.0652 \\
$\quad$ Female & $284(72.5)$ & $161(56.7)$ & $123(43.3)$ & \\
Residency year & & & & \\
$\quad$ First & $79(20.2)$ & $46(58.2)$ & $33(41.8)$ & 0.6392 \\
Second & $183(46.7)$ & $98(53.5)$ & $85(46.4)$ & \\
$\quad$ Third & $130(33.2)$ & $67(51.5)$ & $63(48.5)$ & \\
Faculty & & & & \\
$\quad$ Paris 5 & $110(28.1)$ & $60(54.5)$ & $50(45.4)$ & 0.7110 \\
$\quad$ Paris 6 & $86(21.9)$ & $46(53.5)$ & $40(46.5)$ & \\
$\quad$ Paris 7 & $88(22.5)$ & $53(60.2)$ & $35(39.8)$ & \\
$\quad$ Paris 11 & $24(6.1)$ & $11(45.8)$ & $13(54.2)$ & \\
$\quad$ Paris 12 & $32(8.2)$ & $15(46.9)$ & $17(53.1)$ & \\
$\quad$ Paris 13 & $21(5.4)$ & $9(42.9)$ & $12(57.1)$ & \\
$\quad$ PIFO & $31(7.9)$ & $17(54.8)$ & $14(45.2)$ & \\
Self reported experience of pre-travel consultation & & \\
$\quad$ Never & $255(65.2)$ & $149(58.4)$ & $106(41.6)$ & 0.0103 \\
$\quad$ Often or occasionnaly & $136(34.8)$ & $61(41.6)$ & $75(55.1)$ & \\
\hline
\end{tabular}


oxygen [6]. Evaluation of fitness to fly is important for patients with underlying.

\section{Contributors}

DN and CR designed the study. DN, FL and YY drafted the paper. All authors revised and reviewed the paper.

\section{Declaration of interests}

The authors declare no conflict of interest.

\section{Funding and role of the funding sources}

This study did not receive any specific funding.

\section{Acknowledgment}

The authors thank Laura Smales (BioMedEditing) for editing.

\section{References}

[1] Lapostolle F, Corège D, Sordelet D, Grave M, Lapandry C, Vivien B, et al. Y a t-il un médecin dans l'avion? Presse Med 2010 Jun;39(6):626-31.

[2] Naouri D, Lapostolle F, Rondet C, Ganansia O, Pateron D, Yordanov Y. Prevention of medical events during air travel: a narrative review. Am J Med 2016 Sep;129(9):1000. e1-6.

[3] Tourtier J-P, Franck L, Cirodde A, Coste S, Debien B. Flight ventilation and BoyleMariotte law. Resuscitation 2011 Aug;82(8):1112.

[4] Van Herck K, Van Damme P, Castelli F, Zuckerman J, Nothdurft H, Dahlgren A-L, et al. Knowledge, attitudes and practices in travel-related infectious diseases: the European airport survey. J Trav Med 2004 Feb;11(1):3-8.

[5] Rovira C, Buffel du Vaure C, Partouche H. Are French general practitioners consulted before travel to developing countries? A cross-sectional study conducted in a French airport. Rev Epidemiol Sante Publique 2015 Aug;63(4):253-8.
[6] Josephs LK, Coker RK, Thomas M. BTS Air Travel Working Group, British Thoracic Society. Managing patients with stable respiratory disease planning air travel: a primary care summary of the British Thoracic Society recommendations. Prim Care Respir J J Gen Pract Airw Group 2013;22(2):234-8. Jun.

Diane Naouri* Service des Urgences, Hôpital Saint-Antoine, Assistance Publique des Hôpitaux de Paris, Paris, France Faculté de Médecine, Université Pierre et Marie-Curie, Paris, France E-mail address: diane.naouri@aphp.fr

Frederic Lapostolle SAMU 93, Hopital Avicenne, Assistance Publique des Hôpitaux de Paris, Bobigny, France Faculté de Médecine, Université Paris 13, Sorbonne Paris Cité, Paris, France

Claire Rondet Faculté de Médecine, Université Pierre et Marie-Curie, Departement de Médecine Générale, Paris, France

Olivier Ganansia Service des Urgences, Groupe Hospitalier Paris Saint-Joseph, Paris, France

Dominique Pateron Service des Urgences, Hôpital Saint-Antoine, Assistance Publique des Hôpitaux de Paris, Paris, France

Faculté de Médecine, Université Pierre et Marie-Curie, Paris, France

Youri Yordanov

Service des Urgences, Hôpital Saint-Antoine, Assistance Publique des Hôpitaux de Paris, Paris, France

Faculté de Médecine, Université Pierre et Marie-Curie, Paris, France Centre de Recherche Epidémiologie et Statistique, INSERM U1153, Paris, France 